\title{
Effects of Different Tillage Systems and Soil Residual Nitrogen on Chickpea Yield and Yield Components in Rotation with Wheat under Dry Farming Areas
}

\author{
Nihal Kayan ${ }^{1 *}$, İmren Kutlu ${ }^{2}$, Nazife Gözde Ayter ${ }^{1}$ and Mehmet Sait Adak ${ }^{3}$ \\ ${ }^{1}$ Department of Field Crops, Faculty of Agriculture, Eskisehir Osmangazi University, 26480, Eskisehir, Turkey \\ ${ }^{2}$ Department of Biosystem Engineering, Faculty of Agriculture, Eskisehir Osmangazi University, 26480, Eskisehir, Turkey \\ ${ }^{3}$ Department of Field Crops, Faculty of Agriculture, Ankara University, 06100, Ankara, Turkey \\ *For correspondence: nkayan@ogu.edu.tr
}

\begin{abstract}
The aims of this study were to determine how the tillage system and residual $\mathrm{N}$ of soil affected chickpea yield and its trait in rotation with wheat under Central Anatolia Region. In this study, two tillage methods viz. conventional and reduced tillage, three crop rotations; wheat-wheat; wheat-fallow; wheat-chickpea and four $\mathrm{N}$ levels of $0,50,100,150 \mathrm{~kg}^{-1} \mathrm{were}^{-2} \mathrm{evaluated}$ for four years duration (2012-2015). Tillage methods were maintained into main plots, crop rotation into subplots and $\mathrm{N}$ levels into sub-sub plots. Only chickpea in continuous rotation with wheat was examined in this study. The results were evaluated according to split plot design with three replicates. Grain yield was higher under conventional tillage (CT) than reduced tillage (RT) in both of the growing seasons. Some important yield components were higher under RT than CT especially in the second growing season. These differences of tillage methods may also be due to climatic conditions. Residual fertilizer $\mathrm{N}$ significantly affected chickpea grain yield which increased with 100 and $150 \mathrm{~kg} \mathrm{~N} \mathrm{ha}^{-1}$ levels. Results also indicated that; conventional tillage may be more appropriate for chickpea in rotation with wheat. Chickpea grain yield was also affected when N fertilizer applied to wheat. (C) 2017 Friends Science Publishers
\end{abstract}

Keywords: Chickpea; Tillage methods; $\mathrm{N}$ fertilizer; Rainfed conditions

\section{Introduction}

Arid and semi-arid areas of the world are of particular concern in relation to food production system of major agroecosystems. Mostly rain-fed cropping is practiced within the prevailing climatic constraints (Steiner et al., 1988). Much of the world's drylands are in developing countries and charecterized by low crop productivity, limited irrigation potential, weak administrative and agricultural research infrastructures, and unrelenting pressure on natural resources due to escalating growth in human and animal populations (Ryan, 2002a and b).

The Central Anatolia region is one of the more important arid and semi-arid areas in Turkey. Fallow-wheat cropping system has been traditionally practised in region. Although fallow, regarded as insurance for the next wheat crop, may confer advantages for rain water accumulation, enhancement or preservation of soil productivity and effective weed control but recent availability of fertilizers and herbicides has reduced the need for fallow. Furthermore, despite improvements in ploughing technicues, accumulation of rain water in soil during fallow years is not as high as expected (Akten, 1984). In effect, wheat yields were determined more by the precipitation received during the spring period of wheat cropping than by water accumulated during fallow (Tosun et al., 1996). Fallow-wheat system in Central Anatolia is inconsistent with the conservation agricultural practices. During the 16 months of the fallow season, there is no residue cover in surface soil and loses its agregation and becomes dust due to frequent tillage operations (Avc1, 2011). Tillage-based conventional systems are aroused concern for soil erosion in many semiarid regions continuously (Lopez-Bellido et al., 2004b). In addition to, increasing demand for food and limitations of land expansion has necessitated reduction and effective use of these fallow areas (Tosun et al., 1996). Legumes are of great importance in rotation, especially in which the fallow lands are intensive. Legumes, produced in rotation with cereals, can contribute to the total $\mathrm{N}$ in the soil and increased yields of the cereal (Herridge et al., 1995; Lopez-Bellido et al., 2004a).

Prominent limiting factor in rainfed crop production in Central Anatolia region is the soil water. Therefore, breeders require to stock and utilize limited rainfall for crop production. Conventional tillage involves more field operations and result in more water loss and soil disturbance

To cite this paper: Kayan, N., İ. Kutlu, N.G. Ayter and M.S. Adak, 2017. Effects of different tillage systems and soil residual nitrogen on chickpea yield and yield components in rotation with wheat under dry farming areas. Int. J. Agric. Biol., 19: 517-522 
than conservation tillage. In contrast, conservation tillage improves the soil's physical properties and water storage (Ozpınar and Çay, 2005), increases infiltration rates (Hao et al., 2000) and reduces erosion (Avc1, 2011). Micucci and Taboada (2006) reported that conservation tillage increased organic matter content in the soil. Pikul et al. (1993) noticed that the conventional tillage could be substituted by conservation tillage without yield loss in research about for the influence of four tillage methods in green pea (Pisum sativum L.) - winter wheat rotation. Lopez-Bellido et al. (2004a) reported that the average chickpea grain yield was higher for conventional tillage than no-till in wheatchickpea rotation.

The aims of this study were to determine how affected the tillage system and residual $\mathrm{N}$ of soil on chickpea yield and its trait in rotation with wheat under Central Anatolia region.

\section{Materials and Methods}

\section{Study Site and Soil}

The field experiment was conducted during the growing periods of 2012-2013 and 2014-2015 under dryland conditions at the experimental area of the Faculty of Agriculture, Eskisehir Osmangazi University, Eskisehir, Turkey (3948' N; 30³1' E, $798 \mathrm{~m}$ above sea level). Eskişehir province has a cold rainy winters and hot dry summers. Climatic data for long term and experimental years are shown in Fig. 1. Long term annual total precipitation is $329.7 \mathrm{~mm}$ and it was 338.5 and $546.1 \mathrm{~mm}$ in the experimental years, respectively. Annual average temperature was $12.65^{\circ} \mathrm{C}$ in $2012-2013$ and $11.13^{\circ} \mathrm{C}$ in 2014-2015. Physical and chemical proporties of the soil at the experimental areas are presented Table 1.

\section{Experimental Design and Treatments}

In this study, two tillage methods viz. conventional tillage (CT) and reduced tillage (RT), three crop rotations [wheatwheat (WW); wheat-fallow (WF); wheat-chickpea (WC)] and four $\mathrm{N}$ levels $\left(0,50,100,150 \mathrm{~kg} \mathrm{ha}^{-1}\right)$ were evaluated in Central Anatolia region for four years. Tillage method was maintained into main plots, crop rotation in to subplots and $\mathrm{N}$ levels into sub-sub plots. Only chickpea in continuous rotation with wheat was examined in this study. Therefore the results were evaluated according to split plot with three replicates.

Tillage: The conventional tillage included mouldboard ploughing followed by one passes of a sweep and/or rototiller cultivation to provide a proper seedbed. The reduced tillage included only sweep plowing and/or rototiller cultivation. Tillage depths for CT and RT were 25-30 and 8-10 cm, respectively. Tillage treatments were made in September during experimental years but when chickpea sown in spring, no planting plots were tilled by rototiller for weeds.

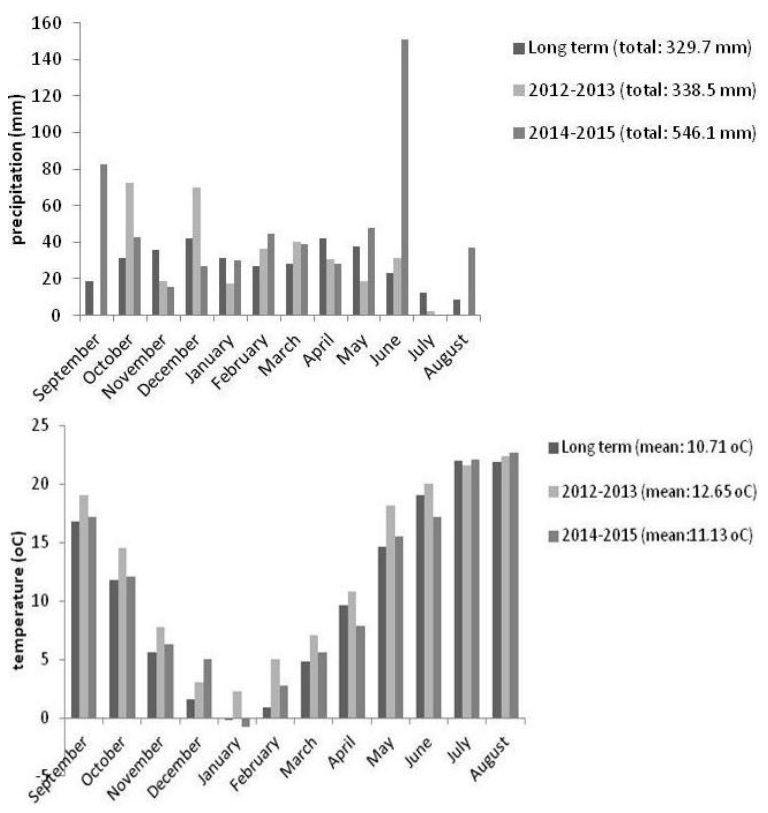

Fig. 1: Total rainfall and monthly mean temperature for two seasons at Eskişehir, Turkey

Crop rotation: Three crop rotations were considered in the experiment. Wheat was sown in all of the plots in the first and third years. In the second and fourth years, wheat, chickpea and fallow were sown and considered on the research plots.

Fertilization: Nitrogen fertilizer was applied to wheat plots as ammonium nitrate. Half was applied at the sowing and the remaining $\mathrm{N}$ topdressed at the begining of the wheat stem elongation. Nitrogen fertilizer levels were applied to only wheat. Basal fertilizer application of $60 \mathrm{~kg} \mathrm{P}_{2} \mathrm{O}_{5} \mathrm{ha}^{-1}$ for wheat, $60 \mathrm{~kg} \mathrm{P}_{2} \mathrm{O}_{5} \mathrm{ha}^{-1}$ and $20 \mathrm{~kg} \mathrm{~N}^{-1}$ for chickpea were applied to each sub-subplot at the time of sowing.

Seeding: Each sub-subplot was $12 \mathrm{~m}^{2}(4 \mathrm{~m} \times 3 \mathrm{~m})$ and $\mathrm{cv}$. Gökçe was used as research material. Chickpea was sown in $30 \mathrm{~cm}$ row spacing at a seeding rate of 60 seeds $\mathrm{m}^{-2}$ on 01 April and 14 April in 2013 and 2015, respectively. No herbicide was applied and weeds were removed by hand. Chickpea was harvested on 29 July and 25 August in 2013 and 2015, respectively.

\section{Crop Yield Measurements}

Flowering time when $50 \%$ plants had flowering, biological yield per plant, pod number per plant, seed number per plant, grain yield per plant $(\mathrm{g})$, harvest index $(\%)$, hundred kernel weight $(\mathrm{g})$ and grain yield $\left(\mathrm{kg} \mathrm{ha}^{-1}\right)$ were measured for chickpea. Biological yield, pod number, seed number and grain yield each per plants were evaluated on 10 randomly selected plants in each sub-subplot. Harvest index were estimated from a $0.25 \mathrm{~m}^{-2}$ area. Each sub-subplot was harvested, mixed and grain yield and hundred kernel weight were estimated (Tosun and Eser, 1975; Aydın, 1988). 
Table 1: Physical and chemical proporties of the soil at the experimental years

\begin{tabular}{lllllllll}
\hline Year & Depth $(\mathrm{cm})$ & Texture & $\mathrm{pH}$ & Total salt $(\%)$ & Lime $(\%)$ & Organic matter $(\%)$ & $\mathrm{P}_{2} \mathrm{O}_{5} \mathrm{~kg} \mathrm{ha}^{-1}$ & $\mathrm{~K}_{2} \mathrm{O} \mathrm{kg} \mathrm{ha}$ \\
\hline $2012-2013$ & $0-30$ & loamy & 7.99 & 0.064 & 3.65 & 1.18 & 34.9 & 2258.6 \\
$2014-2015$ & $0-30$ & loamy & 7.46 & 0.020 & 5.40 & 1.63 & 65.3 & 3630.0 \\
\hline
\end{tabular}

Table 2: Effect of different tillage methods and nitrogen levels on some charecters of chickpea in 2012-2013 growing season

\begin{tabular}{|c|c|c|c|c|c|c|c|c|}
\hline Treatments & FT (day) & BYP (g) & PNP & SNP & GYP (g) & $\mathrm{HI}(\%)$ & $\mathrm{HKW}(\mathrm{g})$ & GY (kg ha- $\left.{ }^{1}\right)$ \\
\hline $\mathrm{CT}$ & 70.17 & 12.25 & 26.06 & 27.41 & 6.87 & $48.95 \mathrm{~b}$ & $42.03 \mathrm{a}$ & $1246.2 \mathrm{a}$ \\
\hline RT & 70.25 & 11.03 & 24.85 & 25.32 & 6.45 & $53.54 \mathrm{a}$ & $40.17 \mathrm{~b}$ & $1110.7 \mathrm{~b}$ \\
\hline Mean & 70.21 & 11.64 & 25.45 & 26.36 & 6.66 & 51.24 & 41.10 & 1178.4 \\
\hline $50 \mathrm{~kg} \mathrm{~N} \mathrm{ha-}{ }^{1}$ & 71.00 & 11.10 & 24.55 & 25.82 & 6.63 & 53.07 & 41.07 & $1197.1 \mathrm{AB}$ \\
\hline $100 \mathrm{~kg} \mathrm{~N} \mathrm{ha-}{ }^{1}$ & 70.00 & 12.04 & 26.43 & 26.58 & 6.63 & 51.41 & 40.38 & $1101.6 \mathrm{~B}$ \\
\hline $150 \mathrm{~kg} \mathrm{~N} \mathrm{ha-}{ }^{1}$ & 69.83 & 12.25 & 26.15 & 27.78 & 7.03 & 50.91 & 41.70 & $1319.3 \mathrm{~A}$ \\
\hline Tillage methods & ns & ns & ns & ns & ns & $*$ & $* *$ & $*$ \\
\hline $\mathrm{N}$ levels & ns & ns & ns & ns & $\mathrm{ns}$ & ns & ns & $* *$ \\
\hline Tillage $\mathrm{x} \mathrm{N}$ levels & $*$ & $* *$ & $* *$ & ns & $* *$ & $\mathrm{~ns}$ & ns & $*$ \\
\hline
\end{tabular}

ns: non-significant, $*: \mathrm{p} \leq 0.05, * *: \mathrm{p} \leq 0.01$. Means in the same column with different letters are significant. FT: flowering time BYP: biological yield per plant PNP: pod number per plant SNP: seed number per plant GYP: grain yield per plant HI: harvest index HKW: hundred kernel weight GY: grain yield

\section{Statistical Analysis}

All data were analysed according to General Linear Model using the Statview package (SAS Institute). Means were compered by Least Significant Differences (LSD) test.

\section{Results}

Harvest index, hundred kernel weight and grain yield were significantly affected by tillage methods but only grain yield by $\mathrm{N}$ levels in 2012-2013 growing season (Table 2). In addition, interaction between tillage methods and $\mathrm{N}$ levels was significant for flowering time, biological yield, pod number, grain yield per plant and grain yield. While 0,50 and $150 \mathrm{~kg} \mathrm{ha}^{-1} \mathrm{~N}$ levels had more time for flowering time in RT and $100 \mathrm{~kg} \mathrm{ha}^{-1} \mathrm{~N}$ level with less flowering time. Thus, interaction between tillage methods and $\mathrm{N}$ levels was significant for flowering time (Fig. 2a). While $150 \mathrm{~kg} \mathrm{ha}^{-1} \mathrm{~N}$ level had highest biological yield per plant and pod number per plant in RT, $50 \mathrm{~kg} \mathrm{ha}^{-1} \mathrm{~N}$ level with lowest values for these traits in same tillage method. Thus, interaction between tillage methods and $\mathrm{N}$ levels was also significant for biological yield per plant and pod number per plant (Fig. $2 \mathrm{~b}$ and $3 \mathrm{a}$ ). The $150 \mathrm{~kg} \mathrm{ha}^{-1} \mathrm{~N}$ showed superior performence under RT for grain yield per plant but no effects was observed for each of the $\mathrm{N}$ levels. Hence, interaction between tillage methods and $\mathrm{N}$ levels was significant (Fig. $3 \mathrm{~b})$. The $150 \mathrm{~kg} \mathrm{ha}^{-1} \mathrm{~N}$ showed superior performence under $\mathrm{CT}$ for grain yield but this performence was not found for each of the $\mathrm{N}$ levels. Therefore, interaction between tillage methods and $\mathrm{N}$ levels was significant (Fig. 4).

Pod number, seed number and grain yield per plant were significantly affected by tillage methods but only grain yield was significantly affected by N levels in 2014-2015 growing season (Table 3). In addition, interaction between

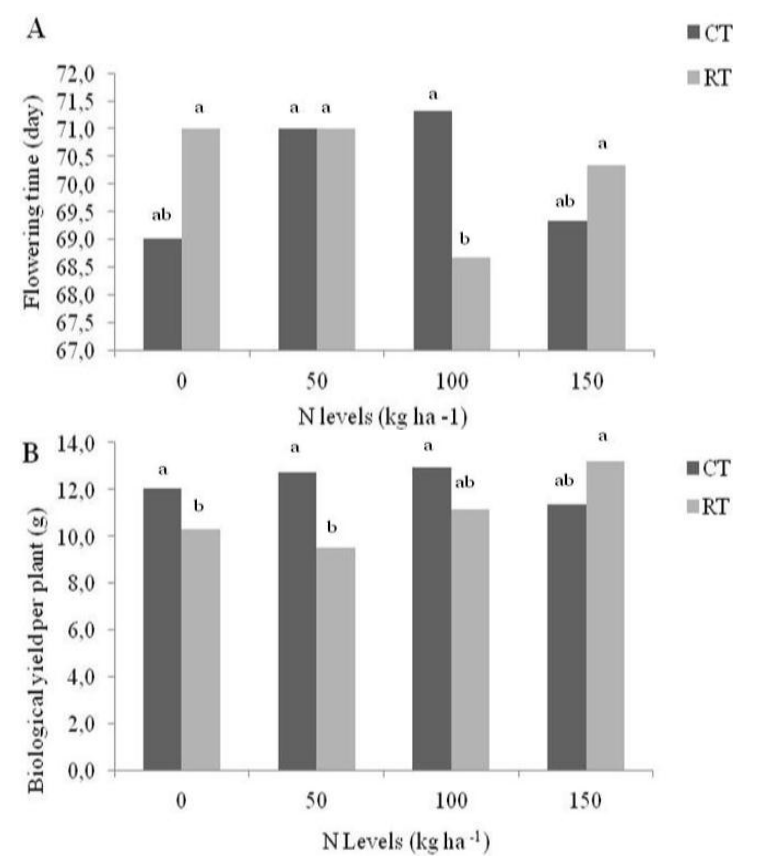

Fig. 2: The interaction between tillage methods and $\mathrm{N}$ levels on flowering time (A) and biological yield per plant (B) of chickpea in 2012-2013[LSD\%5: 2.269 (A); LSD\% 1: 2.688 (B)]

tillage methods and $\mathrm{N}$ levels was significant for biologigal yield, pod number, grain yield per plant and grain yield. The $50 \mathrm{~kg} \mathrm{~N} \mathrm{ha}^{-1}$ showed superior performence in RT for biological yield, pod number and grain yield per plant but same $\mathrm{N}$ levels caused better performance in $\mathrm{CT}$ for all parameters. Hence, interaction between tillage methods and $\mathrm{N}$ levels was significant (Fig. 5a, 5b and 6a). 
Kayan et al. / Int. J. Agric. Biol., Vol. 19, No. 3, 2017

Table 3: Effect of different tillage methods and nitrogen levels on some charecters of chickpea in 2014-2015 growing season

\begin{tabular}{|c|c|c|c|c|c|c|c|c|}
\hline Treatments & FT (day) & BYP (g) & PNP & SNP & GYP (g) & $\mathrm{HI}(\%)$ & HKW (g) & GY $\left(\mathrm{kg} \mathrm{ha}^{-1}\right)$ \\
\hline CT & 61.92 & 26.42 & $21.23 \mathrm{~B}$ & $23.68 \mathrm{~B}$ & $9.70 \mathrm{~B}$ & 31.86 & 39.46 & 1418.00 \\
\hline RT & 62.92 & 29.67 & $24.50 \mathrm{~A}$ & $29.15 \mathrm{~A}$ & $12.11 \mathrm{~A}$ & 30.50 & 39.88 & 1356.00 \\
\hline Mean & 62.42 & 28.04 & 22.90 & 26.41 & 10.90 & 31.18 & 39.67 & 1387.00 \\
\hline $0 \mathrm{~kg} \mathrm{~N} \mathrm{ha-}{ }^{1}$ & 62.67 & 28.65 & 23.78 & 27.33 & 11.57 & 32.02 & 39.19 & $1327.00 \mathrm{~B}$ \\
\hline $50 \mathrm{~kg} \mathrm{~N} \mathrm{ha}^{-1}$ & 61.67 & 29.11 & 23.43 & 28.09 & 11.69 & 29.47 & 39.75 & $1324.00 \mathrm{~B}$ \\
\hline $100 \mathrm{~kg} \mathrm{~N} \mathrm{ha}^{-1}$ & 63.50 & 27.15 & 22.53 & 25.13 & 10.31 & 30.77 & 39.59 & $1602.00 \mathrm{~A}$ \\
\hline $150 \mathrm{~kg} \mathrm{~N} \mathrm{ha}^{-1}$ & 61.83 & 27.27 & 21.85 & 25.10 & 10.04 & 32.46 & 40.15 & $1294.00 \mathrm{~B}$ \\
\hline Mean & 62.42 & 28.04 & 22.90 & 26.41 & 10.90 & 31.18 & 39.67 & 1387.00 \\
\hline Tillage methods & ns & ns & $*$ & $* *$ & $* *$ & ns & $\mathrm{ns}$ & $\mathrm{ns}$ \\
\hline $\mathrm{N}$ levels & ns & ns & ns & ns & $\mathrm{ns}$ & ns & ns & $* *$ \\
\hline Tillage x N levels & ns & $*$ & $*$ & ns & $* *$ & ns & ns & ** \\
\hline
\end{tabular}

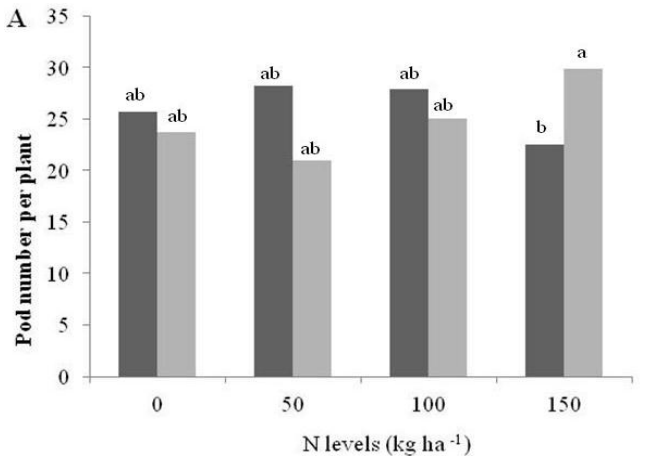

B

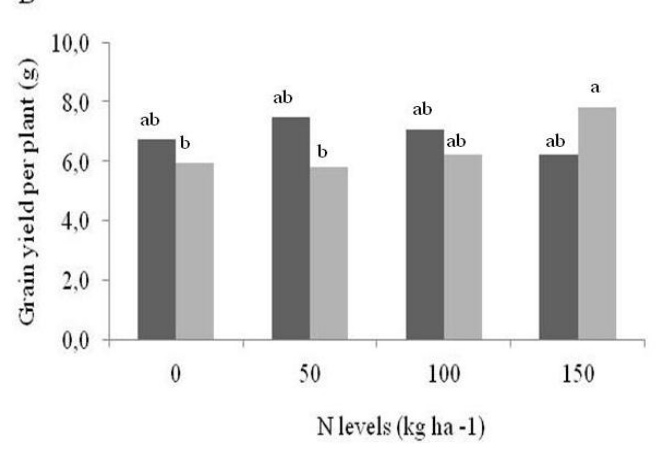

Fig. 3: The interaction between tillage methods and $\mathrm{N}$ levels on pod number per plant (A) and grain yield per plant (B) of chickpea in 2012-2013 [LSD \%1: 6.588 (A); $1.724(\mathrm{~B})]$

$100 \mathrm{~kg} \mathrm{ha}^{-1} \mathrm{~N}$ levels had highest grain yield in CT and $150 \mathrm{~kg} \mathrm{ha}^{-1} \mathrm{~N}$ levels with lowest grain yield in same tillage method (Fig. 6b).

\section{Discussion}

Harvest index was higher for RT than CT but hundred kernel weight and grain yield were higher for CT than RT in 2012-2013 growing season. Lopez-Bellido et al. (2004a) reported that thousand seed weight and grain yield was higher in the CT than no-tillage for chickpea. When $\mathrm{N}$ applied to the preceding wheat, it significantly affected

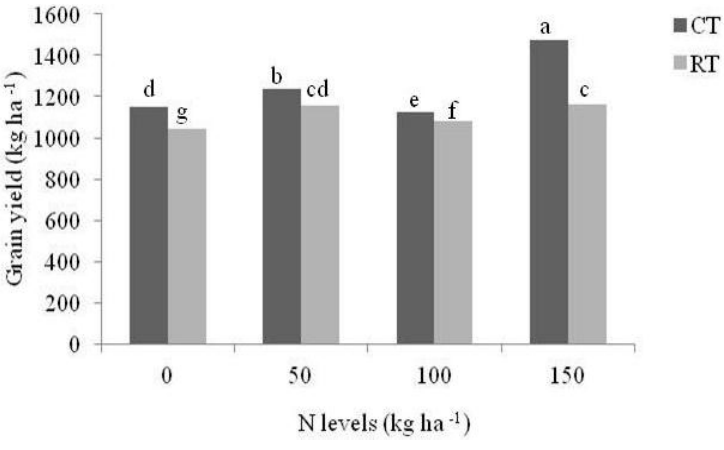

Fig. 4: The interaction between tillage methods and $\mathrm{N}$ levels on grain yield of chickpea in 2012-2013 (LSD\%5: 12.935)

chickpea grain yield. Increasing $\mathrm{N}$ levels increased grain yield and the highest grain yield was obtained for $150 \mathrm{~kg} \mathrm{~N}$ $\mathrm{ha}^{-1}$. It was also reported that increasing $\mathrm{N}$ levels increased grain yield in chickpea when $\mathrm{N}$ applied to preceding wheat (Lopez-Bellido et al., 2004a).

Total precipitation during the 2014-2015 growing season and long term were 546.1 and $329.7 \mathrm{~mm}$, respectively. Mean temperature for growing season was near the long term but total precipitation was very higher than long term [especially June (151.1 mm)] (Fig. 1). In addition, organic matter, $\mathrm{P}_{2} \mathrm{O}_{5}$ and $\mathrm{K}_{2} \mathrm{O}$ in soil was higher this season than 2012-2013 growing season (Table 1). Therefore, grain yield and yield components of chickpea was particularly higher in the 2014-2015 growing season. Only harvest index values were lower than normal because of more vegetative development. Pod number, seed number and grain yield per plant were higher for RT than CT. Some researchers reported that RT gave higher kernel per spike than CT (Hemmat and Eskandari 2004a, b; Ozpinar, 2006). There was no statistically significant difference in grain yield between the two tillage methods for chickpea in this season. But grain yield was higher for CT than RT. Hao et al. (2001) reported that higher grain yield was obtained in CT than minimum tillage for chickpea. Chickpea grain yield was higher for CT than no-till (Lopez-Bellido et al., 2004a). 


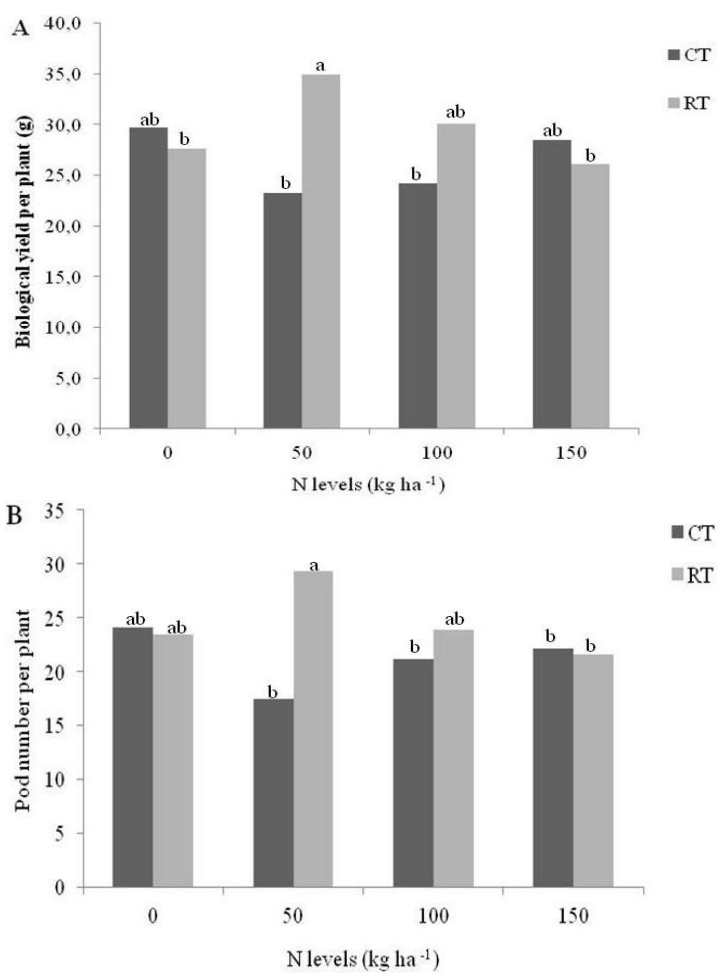

Fig. 5: The interaction between tillage methods and $\mathrm{N}$ levels on biological yield per plant (A) and pod number per plant (B) of chickpea in 2014-2015 [LSD\%5:6.524 (A); 6.446 (B)]

When $\mathrm{N}$ levels applied to preeceding wheat, chickpea grain yield was significantly affected. Grain yield was lower at 0 , 50 and $150 \mathrm{~kg} \mathrm{~N} \mathrm{ha}^{-1}$ and no significant differences between these three levels but highest grain yield was obtained at 100 $\mathrm{kg} \mathrm{N} \mathrm{ha}{ }^{-1}$. Lopez-Bellido et al. (2004a) reported that 100 and $150 \mathrm{~kg} \mathrm{~N}$ ha $^{-1}$ increased chickpea grain yield when $\mathrm{N}$ levels applied to preeceding wheat.

\section{Conclusion}

The highest grain yield of chickpea was obtained CT in both growing season but RT caused higher value for some important yield components, especially second growing season. These differences of tillage methods may also be due to climatic conditions. Effects of tillage might not occur in a short duration and there is a need for long-term research. 100 and $150 \mathrm{~kg} \mathrm{~N}^{-1}$ gave the highest grain yield in the 2014-2015 and 2012-2013 growing seasons, respectively. It may be suggested that conventional tillage can be used for chickpea in rotation with wheat. It was determined that chickpea grain yield was significantly affected residual fertilizer $\mathrm{N}$.

\section{Acknowledgements}

This research was supported in part by Eskişehir Osmangazi University Research Foundation as Project no: 201123039.

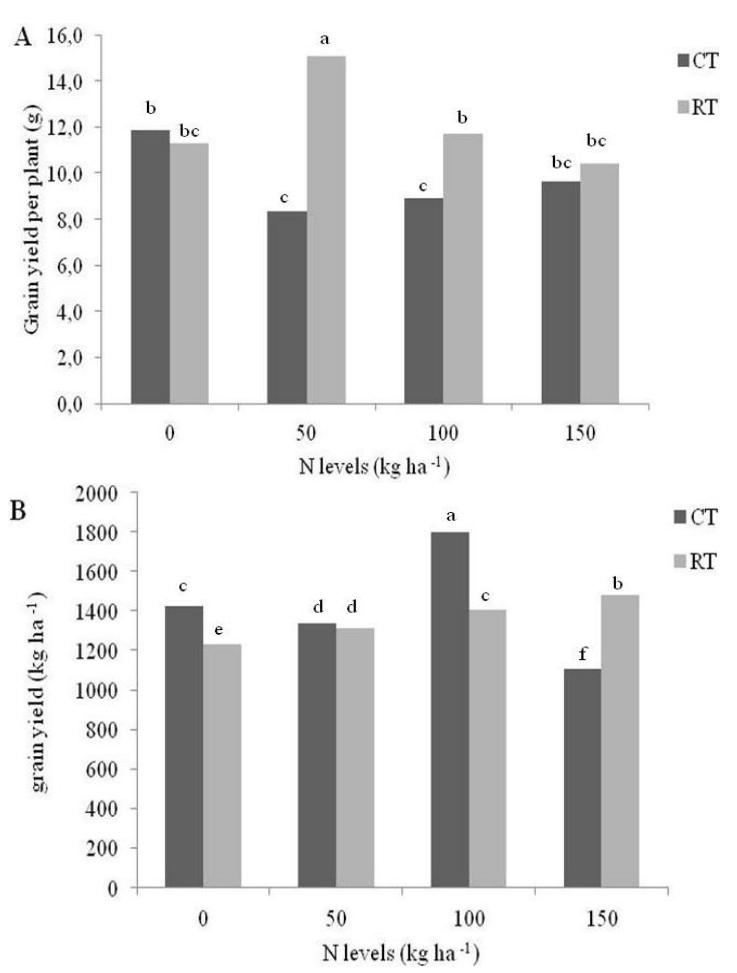

Fig. 6: The interaction between tillage methods and $N$ levels on grain yield per plant (A) and grain yield (B) of chickpea in 2014-2015 [LSD\%1:2.801 (A); 27.336 (B)]

\section{References}

Akten, S., 1984. A study on effective use of fallow lands in South Eastern Anatolia (Turkish with English summary). In: Conference on the Use of Fallow Areas, pp: 59-70. Ankara, Turkey

Avc1, M., 2011. Conservation tillage in Turkish dryland research. Agron. Sustainable Develop., 31: 299-307

Aydın, N., 1988. Effect of sowing time and plant density of the yield, yield components and scochyta blight in chickpea (Cicer arietinum L.) under Ankara conditions. PhD thesis, Ankara University Science Institute, Ankara, Turkey

Hao, X., C. Chan, F.J. Larney, J. Nitschelm and P. Regitnig, 2000. Effect of minimum tillage and crop sequence on physical properties of irrigated soil in southern Alberta. Soil Till. Res., 57: 53-60

Hao, X., C. Chang, R.L. Conner and P. Bergen, 2001. Effect of minimum tillage and crop sequence on crop yield and quality under irrigation in a southern Alberta clay loam soil. Soil Till. Res., 59: 45-55

Hemmat, A. and I. Eskandari, 2004a. Conservation tillage practices for winter wheat-fallow farming in the temperate continental climate of Northwestern Iran. Field Crops Res., 89: 123-133

Hemmat, A. and I. Eskandari, 2004b.Tillage system effects upon productivity of a dryland winter WC rotation in the nortwest region of Iran. Soil Till. Res., 78: 69-81

Herridge, D.F., H. Marcellos, W.L. Felton, G.L. Turner and M.B. Peoples, 1995. Chickpea increases soil-N fertility in cereal systems through nitrate sparing and $\mathrm{N}_{2}$ fixation. Soil. Biol. Biochem., 27: 545-551

Lopez-Bellido, L., R.J. Lopez-Bellido, J.E. Castillo and F.J. Lopez-Bellido, 2004a. Chickpea response to tillage and soil residual nitrogen in continuous rotation with wheat I. Biomass and seed yield. Field Crops Res., 88: 191-200 
Kayan et al. / Int. J. Agric. Biol., Vol. 19, No. 3, 2017

Lopez-Bellido, R.J., L. Lopez-Bellido, J.E. Castillo and F.J. Lopez-Bellido, 2004b. Chickpea response to tillage and soil residual nitrogen in a continuous rotation with wheat II. Soil nitrate, $\mathrm{N}$ uptake and influance on wheat yield. Field Crops Res., 88: 201-210

Micucci, F.G. and M.A. Taboada, 2006. Soil physical properties and soybean (Glycine max, Merrill) root abundance in conventionally and zero-tilled soils in the humid Pampas of Argentina. Soil Till. Res., 86: $152-162$

Ozpınar, S. and A. Çay, 2005. Effects of minimum and conventional tillage systems on soil proporties and yield of winter wheat (Triticum aestivum L.) in clay-loam in the Çanakkale Region. Turk. J. Agric. For., 29: 9-18

Ozpinar, S., 2006. Effects of tillage on productivity of a winter wheatwetch rotation under dryland Mediterranean conditions. Soil Till. Res., 89: 258-265

Pikul, J.L., R.E. Raming and D.E. Wilkins, 1993. Soil properties and crop yield among four tillage systems in a wheat-pea rotation. Soil Till. Res., 26: 151-162
Ryan, J., 2002a. Desert and dryland development: Challenges and potential in the new millennium. In: Proceedings of the " 6 th International Conference on the Development of Dry Lands, p: 655. Cairo, Egypt

Ryan, J., 2002b. Available soil nutrients and fertilizer use in relation to crop production in the Mediterranean area. In: Soil Fertility and Crop Production, pp: 213-246. Krishna, K.R. (eds.). Science Publications Inc, Enfield, New Hampshire, New York, USA

Steiner, J.L., J.C. Day, R.I. Papendick, R.E. Mayer and A.R. Bertrand, 1988. Improving and sustaining productivity in dryland regions of developing countries. Adv. Soil Sci., 8: 79-122

Tosun, O. and D. Eser, 1975. Nohut (Cicer arietinum L.)'ta ekim siklığı araştırmaları, I. ekim sıklığının verim üzerine etkileri. Ankara Üni. Agric. Fac., 25: 171-180

Tosun, F., M. Altın, S. Akten, A. Akkaya, Y. Serin, N. Cessil, F. Kantar and Ö. Çağlar, 1996. Wheat yields in relation to cropping systems under rainfed conditions in Eastern Anatolia. Asp. Appl. Biol., 47: 371-374

(Received 10 August 2016; Accepted 13 March 2017) 